\title{
ROLE OF MEDICINAL PLANTS - INDIA'S RICHEST NATURAL RESOURCE IN TODAY'S HEALTH AND EDUCATION
}

\section{* Prathibha Vinay}

The knowledge of Medicinal plants dates back since the origin of mankind. However, a more systematic approach has been given by the age old Science "Ayurveda" The Science of Life and other systems of medicine such as Siddha, Unani, Homeopathy, etc. Folk medicine is in practice in various parts of the country by both rural and urban people. For centuries Indians have perpetuated an empirical Science of Herbology in relation to health.

The wide spread and long standing practice of using medicinal plants have been transcribed through Vedic Literature, and various scriptures, like in the Holy Bible, mention has been made about use of plants as food and medicine in the Chapter of Genesis and in Epics of Ramayana and Mahabharatha etc.

Traditionally Indian medicine seems to have originated from Mythical through semi mythical and historical events.

During the $6^{\text {th }}$ century B.C. two great universities existed namely, Kasi [Benaras University] in the East and Taxila University in the west. Due to various invasions much damage has occurred to this Science. During the $19^{\text {th }}$ century attempts were made by western scholars to study the Indian System of Medicine.

* Founder President of Tulsi, Vinaya Ashirwad, J.P. Nagar, Bangalore- 560 078, e-mail: tulsihome@yahoo.co.in 
To understand the curative quality and efficiency of the plants, one should develop harmony between oneself and nature, as the human body is made up of the five essential elements - water, air, fire [heat] space \& earth which form the characteristics of a human body known as VAT A - PITTA - KAPHA, types the- TRIDOSHAS.

In the beginning of $20^{\text {th }}$ Century German scholars like Julius Jolly and Neurenberger published manuscripts explaining the scope and achievements of Indian System of medicine. Today we are seeing an exciting revitalization of interest in ancient traditions as it is being proven by experience, particularly in the field of Primany Health Care dealing with the purification of body mind and soul, a discipline which is the insignia of life, by using medicinal plants which is India's precious Natural Resource.

Medicinal Plants have a unique quality of not just having curative, and preventive effect but also protective. They are economical and excellent if used in proper dosage and at appropriate time.

\section{THE TRIDOSHAS}

The Tridoshas [Or three doshas] are the primary and essential factors in the human body that govern our entire physical structure and function. They are called Vata, Pitta and Kapha derived from the five basic eternal substances, the panchabhutas. Each dosha has a predominance of one of the five Bhutas. Vata - consists of the combined predominance of Vayu and Akasha [air and space]. Pitta - consisting of tejas and Jala [fire and water] and Kapha is formed by Jala and Prithvi [Water and earth]. In a healthy body, the three doshas are in balance or in a state of equilibrium.

Many of the physical and mental phenomenon ascribed to the nervous system by modem physiology can be identified with VAT A. Similarly the entire chemical process operating in the body can be attributed to PITT A, including hormones and the complete nutritional system. The activities of the skeletal and anabolic system involved in constructing the physical body can be attributed to KAPHA - suggesting that the entire physical volume in a living organism is the result of Kapha.

\section{Diseases caused by Abnormal Doshas}

When the three doshas are imbalanced or in abnormal state, they cause various types of diseases as follows:

Unbalanced Vata - causes rheumatism, arthritis, musculoskeletal pain, circulatory problems; stomach pain, and constipation; in unbalanced Pitta - causes acidity, skin eruption, irritability, anger and hysteria. 
Unbalanced Kapha causes obesity, drowsiness, nausea, bronchitis, asthma, heaviness in the head and loss of memory. The early stage of imbalance can be termed as the pre-organic level of disease which can be treated by Ayurvedic system. However, Ayurveda is a traditional system of Health Care developed in India over 25,000 years ago and has a great value of not only a system that treats the disease but more a preventive system that focuses on life and healthy living. It seeks to attain and maintain optimum balance [homeostasis] of various hormones, enzymes, tissues, and organs of the body as well as the balance of intellect and emotions of the mind. Thus, the balance of mind and body gives rise to pure consciousness in our lives at every level of existence. Thus, the pre-organic level could be treated.

In order to combat the doshas at a primary level such as, on the immediate on set of any common ailments like simple headaches, hair loss, pimples, memory loss, ear ache, throat ache, stomach disorders., bronchitis tooth ache, common colds, diarrhea, dysentery, constipation, piles, liver disorders, kidney ailments, menstrual disorders in women, high blood pressure, diabetes, excess sweating in palms and souls and other common ailments, there are specific plants for specific ailments which are effective.

In the Ayurvedic system of medicine with a codified system, plants are classified according to their utility and disease such as:

Kayachikithsa

Bhuta chiktisa

Kumara Vidya

Shalya Vidya

Visha Vidya

Vashikama Vidya

Rasayana Vidya

Amrutha
- Plants that cure the diseases of the body

- Plants that cure the disease of mind

- Plants for procreation and protection of children

- Plants for wounds

- Plants as antidotes

- Plants for virility

- Plants for prolongation of life

- Plants used for celestial drink

Our Ancient Indians learnt by experience, intuition and knowledge about the characteristics and their usefulness to mankind in innumerable ways. Since, they are Nature's Gift, man began to recognize and worship nature and many trees, shrubs and herbs as well.

There are plants that protect life and also there are plants that are poisons and kill life. This awareness lead to the preservation, conservation and protection of these life giving plants by the Ancients, as they invested them with divine power for example, plants like Neem, Peepul, Balva , Tulsi ,Amla and many others. 
According to the Ancient traditions, an individual served the community as a teacher, healer and preacher who appraised the people about the importance of plants with medicinal and nutritional value. Ironically today, man in his quest for materialistic gains has ignored health and discipline which is the basic insignia of Life.

However, in this article a few common, important and sacred plants of high medicinal value is dealt, with such as TULSI, NEEM, BIL WA, PEEPUL, AMLA for awareness.

\section{TULSI - Holy basil Tulsi, Ocimum sanctum Linn. (Lamiaceae)}

Tulsi is being spiritually honored as a sacred plant by millions through ages. In the ancient scriptures Tulsi holds a supreme place among various medicinal plants. It is considered to be the mother medicine of nature possessing immense medicinal values. It activates the element of fire in the body. It is widely and popularly used in primary health problems such as common colds, fevers, soar throat, inflammation gastric ulcers, digestive power, as well as for antibacterial, antiviral and antifungal activity and insect bites. It is also known to be a good mosquito and insect repellent. It is both a preventive and curative agent in dealing with degenerative disorders such as cancer, heart disease diabetes and certain neurological problems, and also as an antistress medicine.

There are varieties of Tulsi such as Sri or Ram Tulsi with light and dark green leaves and Krishna Tulsi with dark purple leaves, the Ocimum sanctum. Tulsi contains Alkaloids, Proteins, glycosides, phenols, saponins tannings and terpenes. The essential oil components are terpenes and phenols which are volatile, the euginol content has a major pharmacological use.

Tulsi is also considered to be having Nutritional value providing Vitamins 'A, Carotenes and minerals such as calcium. Best results are obtained by taking fresh leaves. In modem clinical application it is taken in the form of capsules prepared from dried leaves. Tulsi Tea is taken as drink which acts as a good refreshner.

BILV A - Beal tree, Aegle marmelos Corr. (Rutaceae)

The Bealleaves are considered to be the best offering to Lord Shiva in Hindu traditions, and worship just as Tulsi leaves are offered as worship to Lord Vishnu. Bealleaves, fruits both raw and ripened and also the bark have been considered to have excellent medicinal properties. The fruit contains marmalosin which is the active constituent and rich in vitamin. The pulp of ripe fruit is aromatic, cooling and is a laxative as well. Raw fruit is good for digestion and produces heat in the body. Liver 
disorders can also can be cured by eating the soft pulp of the fruit. Leaves are crushed into smooth paste and used as external application over the closed eyes to cure burning sensation and swelling. The juice of the leaves is applied allover the body before bath to be free from body odours and for a clean fresh feel. The matured bark contains the alkaloid aegelenine, used to cure fevers.

\section{SANDALWOOD - Chandana santalum album Linn (Santalaceae)}

Temples in coastal Karnataka have a tradition of giving a small quantity of sandal wood paste for its medicines property.

The sandalwood soap and oil from Karnataka state is well known all over the world for its aromatic oil which imparts a unique fragrance. The sandal tree is highly valued for its refreshing oil in the wood The heartwood yields essential oil containing a substance called santalol. The oil is not only an antiseptic but contains high medicinal values. Small quantity of sandal wood ..dissolved in water is given to quench thirst and prevents colds, fever and cough; the paste applied to the fore head prevents headache, cures skin diseases and pimples; for mouth wash,. sandal wood paste with a combination of lemon juice in a cup of water is taken to cure mouth ulcers. Sandalwood powder in combination with honey is used to control venereal disease as well.

\section{NEEM - Nimba, Bevu, Aazadirachta Indica [Meliaceae]}

The Persian name for Neem is Azad-Darakth meaning free - tree. But, it is no more a free tree as it has been patented by the west. Neem plays an important role in the indigenous system of medicine.

Environmental pollution is the main concern of today world and an unbearable threat to human health. Neem is considered as the antidote to pollution and it purifies the atmosphere by increasing the level of oxygen. It also influences the life of human being physically, mentally and spiritually and is described in the vedic literature as the cure for all diseases. It has varies uses such as, treatment of hair infested with lice, digestive track and lung disorders, urinary infections, and vaginal disorders etc. Neem leaves, fruits and bark are generally used for the preparation of various forms of ayurvedic drugs. In modem medicine it is used for soaps, tooth paste, insecticides pesticides etc. One of the active ingredients isolated from neem is the substance called Azadirachtin which repels insects Meliantriol inhibhits insects from eating the crops. Bitter substances such as Nimbin and Nimbidin. from Neem oil is a good suppressor of Pathogenic species and is being used as antibacterial 
for bacteria such as staphylococcus, a common source of food poisoning and" pus forming disorders; for Typhoid caused by the bacterium salmonella typhosa living in food and water and also for curing blood poisoning and intestinal inflammation. Juice from neem leaves are used for conjunctivitis, as ear drops with honey to

- reduce oozing from ears and inflammation; powder from neem seeds, or neem twig is used for healthy gums and teeth. Ash from neem barks to remove urinary stones.

For dysmenorrhea, neem leaf juice with ginger releases the menstrual pain. Neem is a good deworming agent, excellent for skin allergies and other skin diseases such as psoriasis.

Thus, neem can be considered as a Kalpa Vrakshna or the wish fulfilling tree for good health. .

\section{PEEPUL TREE - ashwatha, Pipal . - Ficus relegiosa Linn. [Moracae]}

Peepul tree the sacred tree among the Hindus is highly venerated. and it is believed that the tree is the abode of the three manifestation of God, accordingly the tree is worshiped through the ages. Besides the sacredness it is considered as a treasure house of a sweet juice which is good cure for cough, biliousness, excessive thirst, a cure for vaginal disorders by faking a decoction from the leaves. Several skin problems such as white and black patches could be cured by taking decoction from the chips of peepul wood.

The medication should be taken under the guidance of an ayurvedic practioner. It is considered that planting and nurturing a peepul tree with its invaluable medicinal properties is a sacred duty. .

\section{AMLA - Amalaki, Emblica Offinaless Gaertn [Euphorbiacae]}

The tree is one among the sacred trees. The fruit is a treasure house of Vitamin ' $\mathrm{C}$. and is used in the human scurvy. Two tablespoons or Gooseberry juice with equal quantity of honey taken every morning cures illness caused by Vitamin 'c' deficiency and also is a good source of brain tonic. It is a rejuvenating agent in premature aging and graying. It also helps to recoup blood loss and increases general immunity and strength. It is a good coolant as well.

There are also records of plant indicators of Environmental Health for example, the tree species of Adina Cordifolia [Rubiaccae] Mangifera indica [mango] 
[Anacardiaceae], which indicate the presence of air pollution by sulphur dioxide. Certain other species of cassia fistula [Fabaceae] olea cuspidata [oleaceae], Prunus cerasoides [Rosaceae] show symptoms like browning of the leaf tip and margins when it comes in contact with the air polluted by hydrogen flouride. Air pollution in the ozone can be diagnosed by observing certain symptoms like, red and brown spots on the leaf surface and, folding of leaves as shown by Pinus roxburghii, Quercus species [Fagaceae]. Picea species [Pinaceae] etc., It has also been found that the medicated air can prevent and contain nagging ailments like tuberculosis and chest diseases by planting trees like Neem, Bilwa, Peepul and Tamarind as they are of high medicinal value.

Tree bark can also work as an exceptionally sensitive indicators of environmental acidity, as the bark could record any changes in the environment due to its capacity of its longevity in the environment. It becomes necessary that all major and private parks be converted to bio-parks with medicinal plants in order to have a healthy living mentally, physically and spiritually.

Thus the role of Medical Botany with emphasis on Ethno-botanical studies with particular reference to the preservation, utilization and propagation of the life sustaining ingredients of nature will be of utmost importance as value based education in the discipline of Botany specifically at the under graduate, levels, where in the students are exposed to natures gift of

self healing as the ingredients from the medicinal plants are richly available in our country, Ironically today, due to various socio-economic, environmental and political changes, there is a great threat to these medicinal plants as nearly one thousand of the eight thousand species of these plants in our country is facing extinction.

For students of botany and other related subjects there appears to be a great scope for future research as we have only touched the tip of the ice berg, considering the vast availability and still unexplored plant species in our country which could be impregnated with high medicinal properties. There is a great promising future for unveiling nature's secret codes by systematic research and analysis for the benefit of humanity and other creations.

In conclusion, health is defined as "State of complete physical, mental and social well being". It is not just being free from disease or infirmity" as signified by WHO [World Health Organiżation] in 1946. In 1978, WHO recommended the integration of traditional health and folk medicine with modern medical therapies for optimal health and welfare of humanity, with a holistic approach. 
It is to be noted that the entire creation is a divine unity, and a co-existence of humans and nature; encouraging such thoughts and attitudes one can achieve the higher goals in life.

The key for all success is . good health, which could be attained by appreciating, understanding, accepting and encouraging sustainable utilization of natural resources, the medicinal plants in particular, which is Gods greatest gift to humanity.

However, the good news is that more and more people in the world are becoming aware and interested in medicinal plants for their nutritional and medicinal properties which are abundantly available, and are cost effective and safe when used in proper doses with the guidance of the practitioner. 